\title{
Constitution and Constitutionalism of Indonesia
}

\author{
Sri Praptini ${ }^{1}$; Sri Kusriyah ${ }^{2}$ and Aryani Witasari ${ }^{3}$
}

Abstract. The term constitution comes from a constituer which means to form, that is, the whole of the rules both written and unwritten which regulate in a binding manner the way a government is held in a society. Constitutionalism in the strict sense is that the administration of the government which islimited by the Constitution, in a broad sense, is a set of political values and aspirations that reflect the desire to protect freedom by carrying out internal and external supervision of government power.There are differences and similarities in the four constitutional ions in Indonesia: a) Procedural aspects: only in the 1945 Constitution, as written and unwritten basic law, are flexible and rigid to adopt the supreme constitution, procedures for establishing and forming by the MPR, other written constitutions; RIS by the Constitutional Assembly, 1950 Constitution by the Constituent Assembly; RIS changes to the constitution with the Federal Law while the 1950 Constitution by the Assembly changes the Constitution; b) Substantial aspects, the form of the Unitary state existed in the 1945 Constitution before and after the changes and the 1945 Constitution, while the RIS of union states, all forms of republic government, recognition of human rights, the system of government of the 1945 Constitution before and after quasi presidential and presidential changes, while RIS and The 1950 Constitution of the Republic of Indonesia, the 1945 Constitution before the change of the highest sovereignty holders of the MPR, the RIS by the Government together with the DPR and the Senate, the 1950 Constitution by the Government and Parliament.

Keywords: Constitution; Constitutionalism; Indonesian Constitution.

\section{Introduction}

The term constitution feels I from a constituer (French) which means forming, is the formation of a country or composing and declaring a country ${ }^{4}$. While the term Basic Law is a translation of "Grondwet". The word "wet" is translated into Indonesian law, and "grond" means land or basis. In countries that use English, the term "constitution" is used which means the constitution ${ }^{5}$. Understanding the constitution can mean more than the definition of the Constitution, but some also equate with the understanding of the Constitution. For political science scholars the term "Contitution" is something broader, that is, all of the written and unwritten rules that tour in a binding manner the ways in which a government is held in a society. ${ }^{6}$

\footnotetext{
${ }^{1}$ Student of Master of Law, Universitas Islam Sultan Agung Semarang and Archive and Library Official of Brebes Regency, email : sritini174@gmail.com

${ }^{2}$ Faculty of Law Universitas Islam Sultan Agung

${ }^{3}$ Faculty of Law Universitas Islam Sultan Agung

4 Ni'matul Huda, 2007, Lembaga Negara Masa Transisi Menuju Demokrasi, UII Press, First Edition, Yogyakarta, p.9 cited from Wirjono Projodikoro, 1989, Asas-asas HTN di Indonesia, Dian Rakyat, Jakarta, p.10.

${ }^{5}$ Sri Sumantri M. , 1993, Susunan Ketatanegaraan Menurut UUD 1945,Sinar Harapan, Jakarta, p.29.

${ }^{6}$ lbid., p.9
} 
W. Van Apeldoorn has clearly distinguished between constitution and grondwet (UUD), if grondwet (UUD) is a written part of a constitution, while constitution (constitution) contains both written and unwritten rules. While Sri Soemantri M., in his dissertation defines the constitution as the same as the Constitution. ${ }^{7}$

There are a number of legal experts who support between the editions and those that equate the definition of the Constitution with the Constitution. Adherents to the ideology that distinguishes the notion of the constitution from the Basic Law include Herman Heller and F. Lassalle ${ }^{8}$. Besides that the constitution is not only juridic, but also contains logical and political meaning ${ }^{9}$.

F. Lassalle in his book "Uber Verfassungswesen", divides the constitution in two senses, namely ${ }^{10}:$ a) Sociological or political understanding (sosiologische or politische begrip). The constitution is a synthesis of real power factors (dereelemacchtsfactoren) in society. b) Juridical understanding (yuridische begrip). The constitution is a text that contains all state buildings and the joints of government.

The compilers of the 1945 Constitution adhere to the sociological thinking above, because in the explanation of the 1945 Constitution it is said: "The constitution of a country is only a part of its basic state law. The basic law is written basic law, while in addition to the National Law it also applies to an unwritten basic law, which is a basic rule that arises and is maintained in the practice of state administration, even if it is not written ${ }^{11 " .}$.

Departing from several expert opinions on the definition of the constitution, draw conclusions that the definition of the constitution includes a written and unwritten constitution. The Basic Law is a written constitution ${ }^{12}$.

According to Miriam Budiardjo, each constitution contains provisions concerning ${ }^{13}:$ a) State organization b) Human rights; c) Procedure for amending the Constitution (amendments); d) Sometimes it contains a prohibition to change certain characteristics of the Constitution. So Miriam Budiardjo's opinion was broader in scope, namely concerning changes to the law.

Problems that arise in state life in developing countries such as Indonesia, in the former colonial countries that are developing are willing to organize constitutions based on the constitution. The constitution inherits the Western legal tradition, but fails to inherit and accept without reserve the basic idea of its constitutionalism regarding the rule of law, the limitations of state power and the guarantee of people's civil rights for its freedom of freedom. Here what happens is not receptio in complexu but rather a decapitation of the concept of the state and Western constitutional law. The constructs and positive norms are understood and accepted, but the basic ideas and meanings are released and not captured ${ }^{14}$.

\footnotetext{
${ }^{7}$ Sri Sumantri M. , 1987,Prosedur dan sistem perubahan Konstitusi, Alumni, Bandung, p.1

${ }^{8}$ Moh. Kusnardi and Harmaily Ibrahim, 1988, Pengantar HTN Indonesia, Pusat Studi HTN, FHUI, Jakarta, p. 65

${ }^{9}$ Ibid., p.11

${ }^{10}$ Abu Daud Busroh and Abu Bakar Busroh, 1991, Asas-asas HTN, Ghalia Indonesia, Jakarta, p.73.

${ }^{11}$ Ibid., p.12

12 Ibid., p.15

${ }^{13}$ Miriam Budiardjo, 2017, Dasar-dasar Ilmu Politik, Cetakan III, PT. Ikrar Mandiri Abadi, Jakarta, p. 177.

${ }^{14} \mathrm{Ni}^{\prime}$ matul Huda, op cit, p. 31
} 
From the description above, there are several formulations which the authors will describe below, among others: Constitutionalism and the study of the understanding of the constitution (Constitutionalism) of Indonesia which is reflected in the constitutions that once took effect in Indonesia.

\section{Discussion}

\subsection{Constitutionalism}

The term constitutionalism was created at the turn of the 18th century to affirm the American doctrine of the supremacy of the Constitution (written constitution) above the laws enacted as the product of the legislature ${ }^{15}$.

In countries that base themselves on constitutional democracy, the Basic Law has a distinctive function, namely limiting government power in such a way that the administration of power is not arbitrary. Thus, it is hoped that the state's human rights will be better protected. This idea is called Constitutionalism ${ }^{16}$.

The idea of constitutionalism as developed in Western Europe, can be repatriated to two of its essence. The first essence, is the concept of the rule of law (the "rule of law") which states that the authority of the law universally overcomes the power of the state, and in relation to that the law will control politics (and not vice versa). The second essence, is that the concept of civil rights of citizens is guaranteed by the constitution and state power will be overcome by the constitution, and even that power may only gain legitimacy from the constitution alone ${ }^{17}$.

The constitution cannot actually be seen apart from the concept of constitutionalism, a concept that has developed before the first constitution was formulated. The main idea of constitutionalism is that the government needs to be limited to its power, so that its implementation is not arbitrary. It is assumed that a constitution is the main guarantee to protect citizens from arbitrary needs. Thus the concept of the constitutional state arises, where the Constitution is considered the most effective institution to protect its citizens through the concept of Rule of Law or Rechsstaat ${ }^{18}$. Thus, the concept of the Rule of Law and Rechtsstaat is the essence of constitutional democracy.

According to Carl J. Friedrich in the book Constitutional Government and Democracy, constitutionalism is the idea that governance is: a collection of activities carried out by and on behalf of the people, but which are subject to some restrictions which are expected to guarantee that the power needed for government is not misused by those who have the duty to govern ${ }^{19}$.

Furthermore Richard S Kay, said that constitutionalism is: Implementation of the rules of law (rule of law) in individual and government relations. Constitutionalism presents

\footnotetext{
${ }^{15} \mathrm{Ni}^{\prime}$ matul Huda, 2007, Lembaga Negara Masa Transisi Demokrasi, UII Press, Yogyakarta, p.24-25

${ }^{16}$ Ibid., p.24

${ }^{17}$ Soetandyo W, 2002, Hukum Paradigma, elsam dan Huma, Jakarta, p. 405

${ }^{18}$ Ibid., p.71

${ }^{19}$ Carl Friedrich,1999, Constitutional Government and Democracy, Cambridge University Press, p.4
} 
a situation that can foster a sense of security, because there are restrictions on the authority of the government that has been predetermined ${ }^{20}$.

Meanwhile, political science scholar Andrew Heywood defines constitutionalism from two points of view. In a narrow sense, constitutionalism is the administration of government which is limited by the Constitution. In other words, constitutionalism exists when government institutions and the political process are effectively limited by the rules of constitutionalism. Whereas in a broader sense, constitutionalism is a set of political values and aspirations that reflect the desire to protect freedom by carrying out internal and external checks on government power ${ }^{21}$. So in this sense constitutionalism is an important part of constitutional democracy.

As a comparison, the author will describe a little about the constitution of Medina, in the seventh century the Prophet Muhammad had formed a political system in accordance with his religious vision by establishing the state of Medina, a system of power and provisions governing the existence of the people of Medina in the Medina Charter or Medina constitution established in in 622 AD, the constitution of Medina was categorized as the first written constitution which regulated political power, human rights, management of community affairs.

The Medina Constitution is a document that underlies the formation of a country, according to Munawir Sadzali, the basic stones that have been laid by the constitution of Medina as a basis for regulating the plural society of Medina $\left.{ }^{22}: 1\right)$ All people sit in Islam even though they come from many tribes but are a community; 2) Relations between fellow members of the Islamic community and the Islamic community and other communities are based on the principles of: a) good neighbors, b) mutual support in the face of common enemies, c) defending those who are persecuted, d) advising each other, e) respecting religious freedom.

About the constitution of Medina RA Nicholson said ${ }^{23}$ : No one can review this treaty document without being impressed by the clarity of its constituent political arena, this agreement is truly a wise and wise thought as well as a new breakthrough. Islam began its state life after the Prophet moved to Yasthrib, which later changed its name to Medina. At Yasthrib or Madinahl ah for the first time a free and independent Muslim community was born under the leadership of the Prophet, and consisted of followers of the Prophet who came from Mecca (Muhajirin) and residents of Medina who had embraced Islam, and who had invited the Prophet to hijr ah Medina (Ansor), but Muslims at that time were not the only community in Medina. Among the residents of Medina there were also other communities, namely Jews and the rest of the Arab tribes who did not want to accept Islam and still remained idol worshipers. In other words, Muslims in Medina are part of a plural society. Shortly after the Prophet settled in Medina, or according to some historians, not enough two years from the arrival of the Prophet in this City, he announced a charter which regulates life and relations

\footnotetext{
${ }^{20}$ Larry Alexander, Constitutionalism, p. 4

${ }^{21}$ Andrew Heywood, 2002, Politics, New York: Palgrave, ed, $2^{\text {st }}$, p. 297.

22 Sri Kusriyah, 2016, Ilmu Negara, Unissula Press, Semarang p. 97 cited from Munawir Sadzali , in Ridwan HR, Fiqih Politik, Gagasan, Harapan dan Kenyataan, Yogyakarta, UII Press, p.135.

${ }^{23}$ Munawir Sadzali , in Ridwan HR, Fiqih Politik, Gagasan, Harapan dan Kenyataan, Yogyakarta, UII Press, p.135.
} 
between communities which are components of a pluralistic society in Medina, Charter it is better known as the Medina Charter ${ }^{24}$.

\subsection{Review Indonesia's constitutionalism (constitutionalism ), which is reflected in the constitutions that once took effect in Indonesia.}

One of the missions of the Constitutional Court is to build constitutionalism. The current constitution, namely the 1945 Constitution has been subjected to change four times, and some still want to change it again ${ }^{25}$.

The most appropriate and solid basis for a democratic country is a constitutional state that relies on a solid constitution as well. A solid constitution is only a constitution that clearly understands its constitution or constitutionalism, which regulates in detail the limits of authority and power of the legislative, executive and judicial institutions in a balanced and mutually controlling manner (checks and balances), and guarantees that are broad enough in the sense to respect, to protect and fulfill the rights of citizens and human rights. In other words, Constitutionalism is a notion of limiting power and guaranteeing people's rights through the constitution. A solid constitution for a constitutional state must also be a legitamate constitution, in the sense that the manufacturing process must be democratically accepted and fully supported by all components of society from various schools and ideologies, aspirations and interests ${ }^{26}$. Constitutionalism contains both procedural / formal, and substantial / material aspects of the constitution. Procedural / formal aspects relate to the procedure of making and procedures for changing institutions, and whether the constitution is supreme or superior or not (for example in relation to international agreements). Substantial / material aspects related to the contents of the constitution which cover issues: a) Form of a unitary state or federal state; $b$ ) Form of republican or royal government; $c$ ) Presidential government system or parliamentary system; d) System of unicameral representation or bicameral system; e) System of division / separation of powers; f) Judicial power system; g) National relations with the people (citizens' rights / human rights); h) Various systems of life in the country (economy, education, defense and security, religion and others) ${ }^{27}$.

From the procedural / formal and substantial / material aspects contained in constitutionalism above, we will describe the study of Indonesia's constitutionalism which is reflected in the constitutions that once took effect in Indonesia as follows: ${ }^{28}$

\section{Constitutionalism in the 1945 Constitution before Amendment}

The constitutionalism contained in the 1945 Constitution before the change can we understand from the principles contained in the Preamble, Body and Explanation, as follows:

\footnotetext{
${ }^{24}$ Sri Kusriyah,2016, Ilmu Negara,Unissula Press, Semarang p. 98

${ }^{25}$ Abdul Mukthie Fadjar, 2006, Hukum Konstitusi dan Mahkamah Konstitusi, Konstitusi Press Jakarta and Citra Media Yogyakarta, p.33

${ }^{26}$ Ibid., p.34-35

${ }^{27}$ Ibid., p.36

${ }^{28}$ Ibid., p.36, 41
} 
- Procedural / Formal Aspects: a) The constitution is defined as basic law (droit constitutionel ) which includes written and unwritten basic laws, namely basic rules that arise and are maintained in the practice of state administration; b) The Constitution is short and sociable, the Indonesian constitution is also flexible and rigid; b) The procedure for establishing (and establishing) a constitution (UUD) is carried out by the highest state institution (MPR); c) From the Explanation of the 1945 Constitution to adopt supreme constitution.

- Substantial / Material Aspects: a) Principles of state unity (integralistic principle); b) The state embodies social justice for all people; c) Countries with popular sovereignty with a system of consultation and representation; d) State based on the Almighty Godhead; e) State based on law (rechtsstaat); f) Government based on the constitutional system, rejecting absolutism; g) The MPR system, namely the MPR as the full implementer of popular sovereignty, is the highest authority holder of the state that sets out the Constitution and GBHN, elects the President and Vice President; h) Unitary State with the form of government republi k; i) The quasi presidential government system, namely the president and DPR are equal, the President is responsible to the MPR, and the Ministers are responsible to the President; j) The power of an independent judiciary; k) The system of local government with the principle of decentralization and deconcentration, as well as respecting the origin of regional privileges; I) Economic democracy with the principle of kinship, where the branches of production are important and those that control the livelihood of many people are controlled by the state; $m$ ) Recognition of human rights in the field of civil and political rights (Freedom of religion, equality in the fields of law and government, freedom of association, assembly, opinion, economic rights, socio-cultural, employment, decent wages, education and others).

Constitutionalism in the RIS Constitution

- Procedural / Formal Aspects: a) A written constitution; b) Establishment of a constitution by Kontitusiante (Constitutional Assembly Body); c) Changes to the constitution with the Federal Law.

- Substantial / material aspects: a) Form of a (federal) union state; b) Form of republican government; c) Parliamentary system of government; d) Type of democratic law state; e) Economic democratic system; e) Bicameral system in representative institutions: Federal Parliament and Senate; f) Complete human rights arrangements; g) Popular sovereignty carried out by the government together with the DPR and the Senate; $h$ ) Independence of judicial power;i) The foundation of the state of the One Godhead, humanity, nationality, popularism and social justice (Pancasila)

Constitutionalism in the 1950 Constitution

- Procedural / Formile Aspects: a) A written constitution; b) Establishment of a constitution by the Constituent Assembly; c) Constitutional / UUD changes by the Assembly of the Constitution.

- Substantial / material aspects: a) State based on Pancasila; b) Form of Unitary State; c) Form of republican government; d) Parliamentary system of government; e) Type of democratic law state; f) Public sovereignty carried out by the government and the DPR; g) Principle of economic democracy; h) General election with a 
proportional system; i) Complete human rights arrangements; j) Local government system with the broadest economy; $k$ ) Independence of judicial power.

Constitutionalism in the 1945 Constitution after Amendment

Changes to the 1945 Constitution lasted four times, changes I (1999), II (2000), III (2001) and IV 92002). These changes adhere to 5 (five) basic principles, namely: a) Not changing the opening of the 1945 Constitution; b) Keep maintaining the form of a unitary state; c) Strengthening the pre sidensilgovernment system ; d) Eliminate explanations and include normative explanations into articles of the Constitution; e) Amendments to the 1945 Constitution are carried out by means of an addendum.

The constitutionalism contained in the 1945 Constitution after Amendment is as follows:

- Procedural / formal aspects: a) A written constitution; b) Formation of the constitution by the MPR; c) Constitutional changes by the MPR with aggravated procedures (is a rigid controversy).

- Substantial / material aspects: a) Pancasila national basis ; b) Form of an united state (may not be changed); c) Form of republican government; d) Presidential government system; e) Type of legal state; f) Soft bicameralism representative institutions (MPR with members from all DPR members and all DPD members); g) People's sovereignty; h) Distribution of power with a system of checks and balances; i) The independence of the judicial power in the hands of the Supreme Court and its judicial bodies underneath and the Court Konsti Tusi; j) The system of local government with the widest possible autonomy; k) Economic democratic system; I) Complete human rights arrangements.

\section{Closing}

\subsection{Conclusions}

Constitutionalism is interpreted from two points of view. In a narrow sense, constitutionalism is the administration of government which is limited by the Constitution. Whereas in a broader sense, constitutionalism is a set of political values and aspirations that reflect the desire to protect freedom by carrying out internal and external checks on government power. Constitutionalism contains both procedural / formal, and substantial / material aspects of the constitution. Procedural / formal aspects relate to the procedure of making and procedures for constitutional change . Of the four Constitutionalism in Indonesia there are differences and similarities: a) Procedural / formal aspects: only in the 1945 Constitution, as written and unwritten basic laws, are flexible and rigid and adhere to supreme constitution, procedures for establishing and forming by the MPR, other written constitutions ; RIS by the Constitutional Assembly and the 1950 Constitution by the Constituent Assembly; RIS changes to the constitution with the Federal Law while the 1950 Constitution by the Assembly changes the Constitution; b) Substantial / material aspects : the form of the Unitary state exists in the 1945 Constitution before and after the changes and the 1945 Constitution, while the RIS states, all forms of republic government, recognition of human rights, the system of government of the 1945 Constitution before and after quasi- residential and presidential changes, while the 1950 parliamentary RIS and 
UUDS, the 1945 Constitution before the change of the highest sovereignty holders of the MPR, the RIS by the Government together with the DPR and the Senate, the 1950 Constitution by the Government and the House of Representatives.

\subsection{Suggestion}

In changing the constitution it should be a legitimate constitution, in the sense that the process of change must be democratic, accepted and fully supported by all components of society from various schools and ideals, aspirations and interests.

\section{Bibliography}

[1] Abdul Mukthie Fadjar, 2006, Hukum Konstitusi dan Mahkamah Konstitusi, Konstitusi Press Jakarta and Citra Media Yogyakarta

[2] Abu Daud Busroh and abu Bakar Busroh, 1991, Asas-asas HTN, Ghalia Indonesia, Jakarta.

[3] Andrew Heywood, 2002, Politics, New York: Palgrave, ed, $2^{\text {st }}$

[4] Carl Friedrich, 1999, Constitutional Government and Democracy, Cambridge University Press

[5] Larry Alexander, Constitutionalism

[6] Miriam Budiardjo, 2017, Dasar-dasar IImu Politik, Cetakan III, PT. Ikrar Mandiri Abadi, Jakarta

[7] Moh. Kusnardi and Harmaily Ibrahim, 1988, Pengantar HTN Indonesia, Pusat Studi HTN, FHUI, Jakarta

[8] Munawir Sadzali, in Ridwan HR, Fiqih Politik, Gagasan, Harapan dan Kenyataan, Yogyakarta, UII Press.

[9] Ni'matul Huda, 2007, Lembaga Negara Masa Transisi Demokrasi, UII Press, Yogyakarta

[10] Wirjono Projodikoro, 1989, Asas-asas HTN di Indonesia, Dian Rakyat, Jakarta.

[11] Soetandyo W, 2002, Hukum Paradigma, elsam dan Huma, Jakarta.

[12] Sri Kusriyah, 2016, Ilmu Negara,Unissula Press, Semarang

[13] Munawir Sadzali, in Ridwan HR, Fiqih Politik, Gagasan, Harapan dan Kenyataan, Yogyakarta, UII Press

[14] Sri Kusriyah, 2016, Ilmu Negara,Unissula Press, Semarang.

[15] Sri Sumantri M. , 1993, Susunan Ketatanegaraan Menurut UUD 1945,Sinar Harapan, Jakarta

[16] Sri Sumantri M., 1987, Prosedur dan sistem perubahan Konstitusi, Alumni, Bandung.

[17] The 1945 Constitution of the Republic of Indonesia Before Change

[18] Constitution of the Republic of Indonesia United 1949

[19] Provisional Constitution 1950

[20] The 1945 Constitution of the Republic of Indonesia Before Change 